\title{
ОСОБЛИВОСТІ КРИМІНАЛЬНОГО ПОКАРАННЯ ЩОДО ФІЗИЧНИХ ОСІБ В АНГЛІЇ
}

Самощенко I. В.

У науковій статmі здійснений аналіз особливостей кримінального покарання щодо фізичних осіб в англійському праві. Вказується, що d законодавстві Англії відсутнє визначення поняття кримінального покарання. Тому воно даються в чисельних судових рішеннях та в доктрині права окремими авторами. Питання ж про цілі покарання наразі вирішено на законодавчому рівні, в Законі про кримінальну юстицію 2003 року, який передбачає їх визначений перелік. Найбільш ж поширеними теоріями покарання в доктрині англійського права є поділ теорій покарання на теорії: а) відплати (retribution); б) залякування (deterrence); в) позбавлення (incapacitation); г) виправлення (rehabilitation).

На відміну від кримінального права України? в англійському праві немає чіткого переліку кримінальних покарань як певної системи їх розташування за ступенем суворості. За відсутності в Англіі кримінального кодексу, покарання не містяться в єдиному законодавчому акті, а розміщені в окремuх cmamymax. Розподіл видів покарання на основні й додаткові не передбачено. Враховуючи чисельні положення статутного права, до видів покарань відносяться: а) покарання, пов'язані з позбавленням волі (custodial sentence) (обмеження волі до 6 місячів, позбавлення волі строкове, на невизначений строк - доки ї Величності буде завгодно, довічне позбавлення волі); б) покарання, які не пов'язані з позбавленням волі (community sentence) (пробація, «суспільне засудження»: виконання певної безоплатної роботи, вимога додержуватися «комендантської години», заборона відвідувати певні місця, вимога пройти курс лікування тощо); в) майнові покарання (штраф, компенсація, конфіскація). Поручі з кримінальними покараннями застосовуються різноманітні заходи кримінально-правового характеру («заходи безпеки»).

Далі розглядаються деякі види покарань, а саме: страта, тюремне ув'язнення, штраф, та інше. Підкреслюється, що починаючи із 2003 року, за англійським законодавством було остаточно встановлено заборону на застосування смертної кари як кримінального покарання за будь-яких умов. тюремне ув'язнення існує лише як єдиний вид позбавлення волі. Режим і порядок відбування цього покарання в місцях позбавлення волі регулюється інструкціями

(c) Самощенко І. В., 2020 і правилами, котрі видає міністр внутрішніх справ. Тюремне ув'язнення диференціюється тільки залежно від його строку. Також детально наводиться процедура визначення судом терміну, який необхідно відбути засудженому до постанови питання про його дострокове звільнення.

Серед покарань, які не пов'язані з позбавленням волі, значне місце займає пробація, а такожпокарання, що становлять зміст «суспільного засудження», тобто різні обмежень прав і свобод особи, передбачені в Законі про кримінальну юстицію 2003 року. Обгрунтовується, що ефективне використання пробації є невід'ємною частиною системи кримінального правосуддя. Ії функціонування повинне забезпечити винесення судами рішень щодо призначення покарань не пов'язаних із тюремним ув'язненням.

Крім того, зазначається, що особливу увагу в застосуванні судами різних видів покарань належить штрафу. Він є найбільш розповсюдженим видом покарання за вчинення злочинних діянь як загального, так і статутного права.

Ключові слова: поняття та мета покарання, види покарань, страта, тюремне ув'язнення, пробація, «суспільне засудження», штраф.

В научной статье осуществлен анализ особенностей уголовного наказания в отношении физических лиц в английском праве. Подчеркивается, что в законодательстве Англии отсутствует определение понятия уголовного наказания. Поэтому оно дается в многочисленных судебных решениях и в доктрине права отдельными авторами. Вопрос же о цели наказания решен на законодательном уровне, в Законе об уголовной юстиции 2003 года, где содержится определенный их перечень.

В отличии от уголовного права Украины, в английском праве нет четкого перечня уголовных наказаний в качестве определенной системы их расположения по степени строгости. При отсутствии в Англии уголовного кодекса наказания не содержатся в едином законодательном акте, а размещены в отдельных стаmутах. Распределение видов наказания на основные и дополнительные не предусмотрено. Рядом с уголовными наказаниями применяются различного рода меры уголовно-правового характера («меры безопасности»).

Далее рассматриваются некоторые виды наказаний, а именно: смертная казнь, тюремное заклю- 
чение, штраф и другие. Указывается, что, начиная с 2003 года, в английском законодательстве окончательно установлен запрет на применение смертной казни. Тюремное заключение существует только как единственный вид лишения свободы. Режим и порядок отбывания этого наказания в местах лишения свободы регулируется инструкциями и правилами, которые выдается министром внутренних дел. Тюремное заключение дифференцируется только в зависимости от его срока, где выделяются его виды: срочное, на неопределенный срок, пожизненное.

Среди наказаний, не связанных с лишением свободы, значительное место занимают пробация, а также наказания, составляют содержание «общественного осуждения», то есть разного рода ограничения прав и свобод личности, предусмотренные в Законе об уголовной юстиции 2003 года. Обосновывается, что эффективное использование пробации является неотъемлемой частью системы уголовного правосудия. Ее функционирование должно обеспечить вынесение судами решений, при назначении наказаний не связанных с тюремным заключением.

Кроме того, отмечается, что особое внимание в применении судами различных видов наказаний отводится штрафа. Он является нашболее распространенным видом наказания за совершение преступных деяний как общего, так и статутного права.

Ключевые слова: понятие и цели наказания, виды наказаний, смертная казнь, тюремное заключение, пробация, «общественное осуждение», штраф.

Samoshchenko I. V. Features of criminal Punishment of individuals in England

The article analyzes the features of criminal punishment of individuals in English law. It states that English legislation does not define the concept of criminal punishment. Thus, this concept recognized in many judicial decisions and teachings of publicists. The issue of the purpose of criminal punishment elaborates at the legislative level in the Criminal Justice Act of 2003, which provides a list of them.

In contrast to Ukrainian criminal law, English law does not have a precise ranking list of criminal penalties according to their severity degree. It mentions that there is no criminal law code in England, so penalties are not contained in a single legislative act, but codified in separate statutes. There is no division of types of punishment into primary and extra. Besides criminal penalties, other measures of criminal punishment ("security measures") applied.

Also, the article describes other types of punishment, such as execution, imprisonment, fines, etc. It emphasizes the ban on the death penalty as a criminal punishment in 2003. Moreover, the penitentiary imprisonment is the only type of custody. The regime and procedure for serving sentences in places of imprisonment must be regulated by instructions and rules issued by the Minister of Internal Affairs. The imprisonment differentiates depending on the term, which distinguishes life sentences, sentences for a specific term.

Also, the article contains the procedure of defining the term served by prisoners before rendering the early release decision. Probation and "public condemnation"', punishments various restrictions on the rights and freedoms of a person occupies a significant place among other non-custodial punishments, provided for in the Criminal Justice Act 2003. The article argues on the problem of the effective use of probation as an integral part of the criminal justice system. The existence of probation must ensure that courts make decisions on non-custodial sentences.

Moreover, it states that special attention in the application of various types of penalties by courts paid to fines. It is the most common type of punishment for criminal acts both common and statute law.

Key words: concept and purpose of punishment, types of punishment, execution, life sentences, probation, "public condemnation", fine.

Постановка проблеми та іï актуальність. Україна як країна, яка прагне до вступу до Європейського Союзу, безумовно, повинна адаптувати своє національне законодавство до правових реалій та приписів, що мають місце у країнах $Є C$. Тому питання щодо дослідження особливостей кримінального покарання в Англії набуває своєї актуальності та значення. Від якості наукових розробок залежить і вирішення питань вдосконалення кримінального законодавства України та іiі правозастосовної практики.

Аналіз останніх досліджень i публікацій. Тема кримінальних покарань в Англії вже привертала увагу науковців як на вітчизняних авторів, так i іноземних. Водночас науковий доробок не $\epsilon$ вичерпним, від потребує постійного доповнення та оновлення. В сучасному розвитку української правової думки ще спостерігається певний дефіцит наукових досліджень із цього питання. Зараз залишаться питання, які потребують своєї популяризації серед науковців та розвитку.

Метою статті $\epsilon$ аналіз англійського законодавства, яке передбачає особливості кримінального покарання щодо фізичних осіб, із використанням доступних наукових та науково-практичних матеріалів, зокрема інформаційних ресурсів: www. legislation.gov.uk, де розміщені чинні закони (статути) Англії.

Виклад основного матеріалу. І. Поняття та мета покарання. У кримінальному законодавстві Англії відсутнє визначення поняття пока- 
рання, тому воно дається в чисельних судових рішеннях та в доктрині права окремими авторами. Зазвичай під покаранням розуміється владне заподіяння страждань особі за вчинення нею злочинного діяння або засіб досягнення «справедливості», тому що держава карає особу, яка сама поставила себе «поза законом» (справа Петтіфера). Найбільш вдалим із цього приводу можна вважати визначення, яке надається Х.Л.А. Хартом. Загалом, за його думкою: а) покарання - це позбавлення, що супроводжується болем, іншими «неприємностями»; б) призначається та виконується державною владою; в) припускає наявність порушення певних норм права, а також формалізоване встановлення його в суді; г) накладається на правопорушника по факту вчинення ним діяння [1, с. 222].

Питання про мету покарання наразі вирішено на законодавчому рівні. Так, Законом про кримінальну юстицію 2003 року (ст. 142) метою покарання в Англії визнано: 1. Покарання злочинця; 2. Зменшення злочинців; 3. Виправлення та ресоціалізація злочинця; 4. Захист суспільства; 5. Відшкодування злочинцем завданих збитків (шкоди) постраждалим від злочину. Крім того, Законом про кримінальну юстицію та імміграцію 2008 року було введено доповнення (ст. 142 (а) до Закону про кримінальну юстицію 2003 року), де основною метою покарання щодо осіб, які не досягли 18-річного віку в системі ювенальної юстицію визначається попередження вчинення злочинних діянь. Таким чином, було здійснено об'єднання цілей покарання у статуті (законі), які до того традиційно визначались у доктрині права.

Найбільше ж поширеними теоріями покарання в англійському праві, які виступають як його триєдина мета, є: а) покарання як відплата за заподіяне зло; б) покарання як залякування; в) покарання як засіб виправлення злочинця [2, с. 261]. Або поділ теорій покарання на теорії: а) відплати (retribution); б) залякування (deterrence); в) позбавлення (incapacitation); г) виправлення (rehabilitation) [3, с. 260-26; 4, с. 95].

Покарання як відплата (retribution) $є$ найбільш стародавньою теорією. Вона має свої витоки в розумінні покарання як «соціального віддання», «помсти з боку суспільства», «справедливої відплати», тобто злочинець підлягає покаранню тому, що він на це заслуговує, та йому спричиняються неприємності через те, що він раніше завдав шкоди будь-кому іншому. Важливим аспектом цієї теорії $\epsilon$ дотримання пропорційного співвідношення суворості покарання серйозності зло- чину, тяжкості шкоди, задля досягнення «балансу справедливості» в суспільстві призначенням саме «справедливого покарання».

Теорія залякування (deterrence) прямо пов'язана з ідеєю І. Бентама, згідно з якою злочинець розглядається як «жертва», яку варто принести в інтересах попередження вчинення нових злочинів. Тому вона містить у собі завдання як загальної (general prevention), так і спеціальної превенції (special deterrence).

Теорія мети покарання, якою $є$ позбавлення (ізолювання) (incapacitation), історичне коріння має в особливостях англійського судочинства. Спочатку, за правилами пенітенціарної системи Англії, тюремне ув'язнення не розглядалось як окреме покарання, а застосовувалося як захід утримання особи до суду та до призначення йому покарання. 3 обранням ув'язненню статусу самостійного покарання позбавлення (ізолювання) втратило цю функцію й набуло значення мети покарання.

Теорія виправлення (rehabilitation) як підстава покарання враховує не факт вчинення злочинного діяння, а небезпечний стан злочинця, що дозволяє застосовувати щодо нього не тільки міру покарання, а й заходи кримінально-правового характеру (так звані заходи безпеки). Крім того, ця мета передбачає здійснення на практиці ресоціализацію злочинця.

II. Система та види покарань. На відміну від кримінального права України, в англійському праві немає чіткого переліку кримінальних покарань як певної системи їх розміщення за ступенем суворості. За відсутності в Англії кримінального кодексу покарання не містяться в єдиному законодавчому акті. Розподіл видів покарання на основні й додаткові не передбачено. Останні можуть застосовуватись в альтернативі або взаємодоповнювати та замінювати один одного. В межах загального права вагому роль щодо визначення виду та розміру покарання надається безпосередньо судам. їх розсуд обмежується у випадках законодавчого визначення санкції за вчинене злочинне діяння.

Ураховуючи чисельні положення статутного права, наразі до видів покарань відносяться: а) покарання, пов'язані з позбавленням волі (custodial sentence) (обмеження волі до 6 місяців, позбавлення волі строкове, на невизначений строк - доки їі Величності буде завгодно, довічне позбавлення волі); б) покарання, які не пов'язані з позбавленням волі (community sentence) («суспільне засудження»: виконання певної безоплатної роботи, вимога дотримуватись «комен- 

та науково-методичне забезпечення

дантської години», заборона відвідувати певні місця, вимога пройти курс лікування алкогольної залежності тощо); в) майнові покарання (штраф, компенсація, конфіскація) [5, с. 58]. Відокремлення тут караності неповнолітніх як певного виду покарань знаходить своє підтвердження у спеціальній літературі [1, с. 222]. Але воно не входить до змісту цього дослідження та потребує додаткової уваги.

Тілесні покарання як архаїчний вид покарання в сучасному кримінальному праві Англії були скасовані з числа останніх у Європі, лише в 1948 році Законом про кримінальну юстицію. Але впродовж до 1967 року вони ще зберігались як дисциплінарні міри впливу на засуджених у місцях позбавлення волі.

Визначення в законі того чи іншого засобу державного примусу як кримінального покарання $\epsilon$ обов'язковим для суду. Ці покарання знаходяться між собою у гнучкій системі співвідношення. Практикою призначення покарання суд має право обрати найбільш суворий його вид та розмір під час установлення так званого «найгіршого випадку» (the worst-case), що носить неординарний, нетиповий характер. Тим самим це поняття виступає одним із критеріїв під час призначення покарання. Наповнення його змісту здійснюється судом за власним розсудом, і в кожному окремому разі воно може бути досить довільним. До таких обставин, яким суд дає оцінки, належать, наприклад, форма вини, спосіб учинення злочинного діяння, обсяг наслідків, характеристика особи винного тощо.

Cmpama (смертна кара). В Англії призначення страти (смертної кари) за вчинене тяжке вбивство (murder) було скасовано спочатку, у 1965 році, Законом про тяжке вбивство (скасування смертної кари) та остаточно з 1970 року. Особи, які визнані судом винними у вчинені тяжкого вбивства, підлягають засудженню до довічного тюремного ув'язнення. В інших випадках страта замінюється або позбавленням волі на невизначений термін, або довічним позбавленням волі.

Крім того, в 1981 році Законом про збройні сили смертна кара скасована за шпіонаж (espionage), із 1998 року Законом про злочини та заворушення - за піратство з насильством (piracy) щодо Закону про піратство 1837 року, за підпал королівських (державних) кораблів, портів, складів щодо Закону про охорону портів 1772 року та за «велику зраду», тобто зраду суверену або державі й надання допомоги ворогові Законом про зраду 1351 року (treason).
У 1999 році та у 2003 році парламентом Англії було схвалено, відповідно, 6-й та 13-й Протоколи до Конвенції про захист прав людини та основних свобод. Тим самим, за англійським законодавством, було остаточно встановлено заборону на застосування смертної кари як кримінального покарання за будь-яких умов.[6, с. 74-75]

Позбавлення волі. Після того, як Законом про кримінальну юстицію 1948 року були скасовані каторжні роботи (кримінальне рабство - «penal servitude»), в Англії $\epsilon$ лише один вид позбавлення волі (custodial sentence) - тюремне ув'язнення. Режим і порядок відбування покарання в місцях позбавлення волі регулюється інструкціями і правилами, котрі видає міністр внутрішніх справ. Тюремне ув'язнення диференціюється тільки залежно від його строку й, відповідно до ст. 89 Закону про повноваження кримінальних судів 2000 року, не може бути призначене особі, що не досягла 21 року.

За можливістю визначити строк ув'язнення його видами в англійському праві можна вважати: строкове, на невизначений строк - доки їі Величності буде завгодно, довічне [4, с. 95]. Тюремне ув'язнення 3 «подовженим» строком, яке було передбачене ст. 227 Закону про кримінальну юстицію 2003 року, виключене із статутного права у 2012 році Законом про правову допомогу під час винесення вироків та покарання правопорушникам.

Завдяки тому, що застосуванням тюремного ув'язнення як виду покарання забезпечується реалізація всіх чотирьох цілей покарання (а саме: відплати, залякування, позбавлення й виправлення), воно має універсальне значення в англійській правовій доктрині. Крім того, це покарання належить до суворих видів покарань і для його застосування мають бути певні підстави. Законом про кримінальну юстицію 2003 року (ст. 152) передбачається, що суд не повинен виносити вирок про призначення тюремного ув'язнення, якщо не прийде до переконання про неможливість досягти мети покарання застосуванням інших видів покарання (наприклад, призначенням штрафу, «суспільного засудження») та коли саме позбавлення волі відповідає ступеню тяжкості злочинного діяння. Однак ніщо не заважає суду призначити позбавлення волі злочинцю, коли він не виражає своєї готовності виконувати вимоги, які входять до наказу про «суспільне засудження» (коли обов'язкова проте потрібна згода самого засудженого), а також у разі його відмови пройти тестування на наркозалежність, відповідно до положень ст. 161 Закону. 
Щодо приписів ст. 89 Закону про повноваження кримінальних судів 2000 року тюремне ув'язнення, як правило, не може призначатися особам, котрі не досягли 21 року. Позбавлення волі у вигляді «ув'язнення на невизначений строк - доки їі Величності буде завгодно» може бути призначено особі у віці до 18 років за вчинення тяжкого вбивства або іншого злочинного діяння, за яке передбачено покарання понад 14 років. У такому разі строк ув'язнення не може перевищувати максимального строку позбавлення волі, що встановлено за вчинене діяння. Особи, які вчинили злочин у віці від 18 до 21 року, можуть бути покарані призначенням ув'язнення на строк, що не перевищує максимального строку позбавлення волі, встановленого за вчинене діяння, якщо, на думку суду, інші заходи поводження із правопорушником у цьому разі недоречні (ст.ст. 90-91 Закону).

Однак на практиці суди Англії стикаються з відсутністю достатньо чітких критеріїв для визначення конкретного розміру покарання. Підставами тут можуть слугувати особливості встановлення санкцій щодо статутних злочинних діянь, де передбачається лише максимальна межа покарання. У санкціях же за злочинні діяння загального права така межа майже не встановлена. Проте, враховуючи положення ст. 132 Закону про магістратські суди 1980 року, мінімальний строк позбавлення волі, яке призначається цими судами не може бути менше 5 днів. Також невизначеність у законі терміну тюремного ув'язнення надає право суду призначити покарання, що не перевищує два роки позбавлення волі (ст. 77 Закону про повноваження кримінальних судів 2000 року).

Під час оцінки серйозності будь-якого правопорушення (злочинного діяння) суд зобов'язаний ураховувати вину злочинця у скоєнні злочинного діяння та шкоду, завдану злочинним діянням (ст. 143 (1) Закону про кримінальну юстицію 2003 року). Звичайною мовою, в загальних рисах суд висловлює причини прийняття ним відповідного рішення у справі, а саме: обрання засудженому певного виду та обсягу покарання (ст. 174 Закону). Крім того, призначення тюремного ув'язнення повинно бути мінімально можливим, на думку суду, з урахуванням тяжкості (серйозності) вчиненого злочинного діяння. Тому суд повинен виносити рішення щодо призначення позбавлення волі, якщо він уважає, що злочинне діяння або декілька злочинних діянь, пов'язані з ним, були настільки серйозними, що обрання штрафу або «суспільне засудження» $\epsilon$ не виправданими покараннями (ст. 153 (2) Закону).
Таке правило не спрацьовує у разі закріплення у статутному праві абсолютно визначених санкцій. Наприклад, саме такою санкцією $€$ санкція ст. 1(1) Закону про тяжке вбивство (скасування смертної кари) 1965 року, де передбачається за вчинення тяжкого вбивства покарання у вигляді довічного позбавлення волі. Або 1. Якщо особа не може виразити своєї готовності виконувати вимоги, які суд має включити до “суспільного засудження» та яке вимагають згоди особи, 2. Особа не виконує наказу щодо тестування наркозалежності. В такому разі суду ніщо не заперечує винести рішення про призначення покарання у вигляді позбавлення волі (ст. 152 (3) Закону про кримінальну юстицію 2003 року) [3, с. 264].

Особливої уваги заслуговує також питання призначення довічного позбавлення волі за англійським статутним правом. Відповідно до ст. 225 Закону про кримінальну юстицію 2003 року, особа у віці 18 років та більше може бути покарана призначенням довічного позбавлення волі (коли санкцією за вчинене ним злочинне діяння передбачається така можливість), якщо, на думку суду, серйозність учиненого виправдовує постанову такого вироку. Якщо санкція за вчинене злочинне діяння або декілька діянь не передбачає покарання у вигляді довічного позбавлення волі, але серйозність (тяжкість) діяння спонукає до необхідності відповідного захисту суспільства (за наявності суттєвих ризиків завдання серйозної шкоди), суд управі призначити особі позбавлення волі на невизначений строк. Таким чином, особа фактично вважається засудженою до довічного позбавлення волі (ст. 34 (2) Закону про злочин (покарання) 1997 року) та може бути звільнена достроково з тих же підстав, що й особи, засуджені до такого ж позбавлення волі.

Також варто зазначити, що під час призначення довічного позбавлення волі суд може зазначити певний термін («тариф»), який необхідно відбути засудженому до постанови питання про його дострокове звільнення (ст. 269 Закону про кримінальну юстицію 2003 року). Рішення щодо тривалості «тарифу» залежить від тяжкості (серйозності) вчиненого злочинного діяння. У встановленні серйозності (тяжкості) злочинного діяння судам належить керуватись трьома «загальними положеннями», які викладені в Додатку 21 до цього Закону.

1. Випадки, які звичайно підпадають під п. 4 (2) Додатку, тобто коли суд уважає, що тяжкість (серйозність) злочинного діяння або декількох злочиннихдіяньє «виключновисокою», асаме: а) вбивство 
двох або більше осіб, коли кожне вбивство містить будь-що з наступного: І. Значна ступінь навмисності або планування, II. Викрадення потерпілого, III. Сексуальні чи садистські дії, b) вбивство дитини, якщо воно пов'язане з викраденням дитини або сексуальними чи садистськими мотивами, b-a) вбивство поліцейського або співробітника тюремної установи під час виконання своїх обов'язків, с) убивство, пов'язане із просуванням політичних, релігійних чи ідеологічних цілій, d) убивство, вчинене особою, яка раніше була засуджена за вбивство.

Відповідно до ч. 4 ст. 269 Закону суд має право постановити, що щодо осіб віком 21 рік та більше у зв'язку з «виключно високою» тяжкістю (серйозністю) вчиненого злочинного діяння або декількох діянь положення про дострокове звільнення на засудженого не розповсюджується. Тому призначення довічного позбавлення волі без права дострокового звільнення вважається найбільш удалою альтернативою смертної кари (страти) [7, с. 18].

2. Випадки, які звичайно підпадають під п. 5 (1) Додатку, тобто коли суд уважає, що тяжкість (серйозність) злочинного діяння або декількох злочинних діянь $є$ «особливо високою», а саме: а) /виключен із п. 5 (1) у 2015 році Законом про кримінальне правосуддя та передбачений зараз як підпункт b-a) п. 4 (2) Додатку/, b) вбивство із застосуванням вогнепальної зброї або вибухових речовин, с) убивство, вчинене заради вигоди (таке як - убивство, вчинене під час пограбування чи берглері або для їх сприяння, вчинене на замовлення або з метою отримання прибутку), (d) вбивство, яке спрямоване на втручання або перешкоджання здійсненню правосуддя, (е) вбивство, пов'язане із сексуальними або садистськими діями, (f) вбивство двох або більше осіб, (g) убивство на расовому чи релігійному ґрунті, або сексуальної орієнтації, (h) вбивство, яке підпадає під дію ч. 4 (2), вчинене у віці до 21 року.

3. Усі інші випадки тяжкого вбивства, що не підпадають під дію п. 4 (2) та п. 5 (1) Додатку та передбачені в п. 6 та п. 7 Додатку, а саме:

- якщо злочинець, під час вчинення злочинного діяння, був у віці 18 років або більше, і справа не потрапляє в межі пунктів 4 (1), 5 (1) або 5А (1), що стає відправним положенням під час визначення мінімального терміну у 15 років;

- якщо злочинець, під час вчинення злочинного діяння, був молодше 18 років, відповідне відправне положення під час визначення мінімального терміну становить 12 років.
Крім того, згідно із п. 8 та п. 9 Додатку, суд повинен взяти до уваги будь-які обтяжуючі або пом'якшуючі обставини тією мірою, якщо вони вже не були враховані у статуті. Це може привести до визначення мінімального строку будь-якої тривалості (незалежно від початкових положень, передбачених у статуті) або прийняття рішення щодо по життєвого засудження.

Обтяжуючими обставинами, які можуть стосуватись убивства, та зазначені в п. 10 Додатку, крім тих, що вказані в п.п. 4 (2), 5 (2) і 5А (2), $\epsilon:$ (a) значна ступінь планування або навмисності, (b) той факт, що потерпілий був особливо вразливий через вік або інвалідність, (c) душевні або фізичні страждання, заподіяні потерпілому перед смертю, (d) зловживання службовим становищем, (е) використання примусу або погроз щодо іншої особи для полегшення вчинення злочинного діяння, (f) той факт, що потерпілий здійснював державну службу або виконував громадські обов'язки, i (g) приховування, пошкодження або розчленування тіла.

Пом'якшуючі обставини, які можуть стосуватись убивства, охоплюють (п. 11 Додатку): (а) намір завдати серйозної шкоди здоров'ю, а не вбити, (b) відсутність навмисності, (c) той факт, що злочинець страждав від будь-якого психічного розладу або розумової неповноцінності, які (хоча й не підпадали під дію п. 2 (1) Закону про вбивство 1957 року (з. 11)), але знизили ступінь його вини, (d) той факт, що злочинець був спровокований (наприклад, тривалим стресом), (е) той факт, що злочинець діяв будь-якою мірою в цілях самооборони або у страху перед насильством, (f) переконання злочинця в тому, що вбивство було актом милосердя, й (g) вік злочинця.

Покарання, не пов'язані з позбавленням волі. Серед зазначених видів покарання значне місце посідають: інститут пробації, а також покарання, що становлять перелік різних обмежень прав і свобод особи, передбачений у Законі про кримінальну юстицію 2003 року.

Отже, пробація (від англ. «probation» - випробування) має свою стародавню історію в Англії, яка започаткована в 1887 році із прийняттям Закону про випробування вперше засуджених та Закону про випробування злочинця 1907 року. Зараз питання щодо пробації регулюються як загальним правом, так і статутним, а саме: Законом «Правила про пробацію 1965 року, Законом про повноваження кримінальних судів 1973 року, Законом про кримінальну юстицію 2000 року. Відповідно до цих законодавчих приписів, суд, під 
час розгляду справи щодо обвинувачення особи у вчинення злочинного діяння, за яке покарання точно не визначено в законі, має право прийняти рішення про наказ про пробацію. У своєму значенні, пробація не передбачає призначення будьякого карного покарання, а лише слугує альтернативною мірою тюремному ув'язненню. Загальна iї ідея полягає в тому, щоб знайти такі важелі впливу наявними пробаційними програмами, які би призвели до зміни поведінки засудженого з усвідомленням ни своєї відповідальності та він став на шлях виправлення. На думку англійських криміналістів, ефективне використання пробації $\epsilon$ невід'ємною частиною системи кримінального правосуддя. Ї̈̈ функціонування повинне забезпечити винесення судами рішень щодо призначення покарань, не пов'язаних із тюремним ув'язненням i які відповідали певному степеню їх суворості й вимогливості [8, с. 5].

Під час постанови наказу про пробацію суд повинен дійти висновку про те, що мета призначення пробації $\epsilon$ бажаною в інтересах забезпечення ресоціалізації злочинця, захисту суспільства від завданої шкоди, попередження нових злочинних діянь (ст. 2 (1) Закону про повноваження кримінальних судів 1973 року). Також суд зобов'язаний проаналізувати всі обставини справи, яка розглядається, надати відповідну оцінку особі винного та отримати з його боку обов'язкову згоду на застосування щодо нього умов пробації.

Особа, щодо якої виданий такий наказ, повинна перебувати під наглядом чиновника служби пробації протягом терміну іспитового строку не менше 1 року та не більше 3 років, виконувати інструкції, які він може від нього отримувати. Протягом іспитового строку на засудженого можуть бути покладені такі зобов'язання (умови пробації): пройти курс програми реабілітації, відшкодувати потерпілому завдану шкоду, не відвідувати заборонені судом місця, відмова від поводження з вогнепальною та іншою зброєю, з'являтись за викликом до служби пробації, працювати лише в дозволених місцях роботи, сповіщати про зміну адреси або мешкати лише в місцях, точно вказаних чиновником служби пробації тощо [9, с. 113; 10].

Наслідками невиконання засудженим умов пробації, згідно з положеннями ст. 6 (3) Закону про повноваження кримінальних судів 1973 року, можуть становити: а) штраф у розмірі $50 £$ фунтів стерлінгів, б) наказ про надання безоплатних послуг суспільству, в) наказ про відвідування центру виховання, г) призначення покарання задля реального його виконання.
Наступними видами покарань, які не пов'язані з тюремним ув'язненням, $\epsilon$ ті відповідні примусові приписи, які передбачені ст. 177 Закону про кримінальну юстицію 2003 року) і становлять зміст «суспільного засудження» (community sentence) (ст. ст. 199-214 Закону):

1. Безоплатні роботи від 40 годин до 300 годин протягом 12 місяців (ст. 199 Закону).

2. Вимога зайнятись реабілітаційною діяльністю (наприклад, яка спрямована на відшкодування завданої шкоди, встановлення контакту з потерпілим) або відвідування певних місць (наприклад, для проходження курсу реабілітації) (ст. 200-А Закону).

3. Навчання за спеціальною соціальною акредитованою програмою (ст. 202 Закону).

4. Заборона на певні види діяльності у визначені дні протягом певного періоду часу (ст. 203 Закону).

5. «Комендантська година» - вимога перебувати строком не менш 2 годин та не більш 12 годин на день у певних місцях протягом 6 місяців (ст. 204 Закону).

6. Заборона перебувати в певних місцях протягом не більше 2 років (ст. 205 Закону).

7. Вимога не покидати місця постійного проживання або постійно перебувати в певному місці, зазначеному судом у наказі (ст. 206 Закону).

8. Вимога на заборону виїзду за кордон у дні або в термін (не більше ніж на 12 місяців), які вказані в наказі (ст. 206-А Закону).

9. Вимога пройти курс лікування психічного захворювання (за згодою особи) (ст. 207 Закону).

10. Вимога пройти курс лікування від наркозалежності (за згодою особи) (ст. 209 Закону).

11. Вимога пройти курс лікування алкогольної залежності (за згодою особи) (ст. 212 Закону).

12. Вимога заборони на вживання алкоголю в період не більше 120 днів та проходження відповідного моніторингу (ст. 212-А Закону).

13. Вимога відвідування спеціального центру присутності для осіб віком до 25 років терміном від 12 до 36 годин, але не більше 3 годин на день (ст. 214 Закону).

14. Електронний моніторинг: застосовується під час призначення вимог щодо «комендантської години» та забороні перебувати в певних місцях (ст. 215 Закону).

Загалом, строк дії «суспільного засудження» не може перевищувати 3-х років. Щодо окремих вимог можуть бути встановлені скорочені терміни (ст. 177 (5) Закону про кримінальну юстицію 2003 року). 
Умовами застосування «суспільного засудження» щодо ст. 148 Закону про кримінальну юстицію 2003 року $\epsilon$ відповідність ступеня серйозності (тяжкості) злочинного діяння ступеню суворості цього покарання, окрім випадків заміни штрафу «суспільним засудженням». Цьому покаранню підлягають особи, яким на момент засудження виповнилося 16 років. Також воно повинно містити в собі умови, які найбільш відповідають особі правопорушника, не суперечить його релігійним уподобанням, не заважають його нормальній роботі або навчанню (ст. 217 Закону).

«Суспільне засудження» призначається як альтернатива позбавленню волі або штрафу й тоді, коли воно прямо не передбачене в санкціях закону. Суд має право призначити його замість позбавлення волі, як правило, за вчинення будьякого злочинного діяння, окрім випадків, наприклад, коли законом передбачене покарання у вигляді довічного позбавлення волі [3, с. 272].

У разі дотримання особою вимог «суспільного засудження», які свідчать про досягнення мети покарання (наприклад, успіхи правопорушника або його задовільне реагування на нагляд чи лікування (залежно від обставин)), магістратський суд, ураховуючи ступінь виконання особою вимог «суспільного засудження», може достроково звільнити особу від покарання або їй може бути призначене інше, більш м'яке покарання (ст.ст. 13-14 додатку 8 до Закону про кримінальну юстицію 2003 року).

У разі порушення вимог «суспільного засудження» з боку особи, котра підлягає покаранню, ці вимоги можуть бути погіршені, або призначене більш суворе покарання в межах санкції, або прийнято рішення про застосування штрафу в розмірі не більш 2500£ фунтів стерлінгів, або призначене позбавлення волі на строк не більш ніж 51 тиждень, якщо порушення «суспільного засудження» було без поважних причин, умисним та наполегливим (ст.ст. 9-10 додатку 8 до Закону про кримінальну юстицію 2003 року).

Штраф. Серед інших видів покарань штраф (fine) посідає в Англії значне місце. Він $\epsilon$ найбільш розповсюдженим у застосуванні судами видом покарання за вчинення злочинних діянь як загального, так і статутного права. За англійською доктриною саме штраф виступає найбільш привабливою мірою державного примусу, під час виконання якого реально відбувається відшкодування завданої шкоди за фактом учинення не тяжкого злочинного діяння з боку засудженого [11, с. 15].
Згідно зі ст.163 Закону про кримінальну юстицію 2003 року штраф може бути призначений: а) як альтернатива замість іншого покарання, або б) одночасно 3 іншим покаранням (наприклад, тюремним ув'язненням, але не разом із пробацією).

Штраф, який призначається магістратськими судами фізичній особі за спрощеною процедурою (без обвинувального акту), на думку суду, повинен відповідати правилам співрозмірності покарання серйозності (тяжкості) вчиненого злочинного діяння, а також підлягає врахуванню матеріального стану засудженого в кожному окремому випадку (ст. 164 Закону про кримінальну юстицію 2003 року). Це положення має значення ще й задля запобігання «зменшення кількості випадків направлення у в’язницю», тобто запобіганню надмірного застосування позбавлення волі, що знайшло своє закріплення в Законі про відправлення правосуддя 1924 року. Призначення судом штрафу та визначення його розміру, як правило, обмежується рекомендаціями, котрі містяться у приписах Великої Хартії Вольностей (“Нabeas corpus Act”) 1679 року і в Біллі про права 1689 року про заборону застосовувати покарання, яке $\epsilon$ надмірним, жорстоким чи незвичайним, тобто практично є необмеженим.

Штраф, який накладається магістратським судом, визначається в розмірі щодо «стандартної шкали штрафів», передбаченій у ст. 17 Закону про кримінальну юстицію 1991 року за відповідними рівнями. Отже, 1 рівень: максимальний розмір штрафу становить $200 £$ фунтів стерлінгів; 2 рівень: 500 £ фунтів стерлінгів; 3 рівень: 1000 £ фунтів стерлінгів; 4 рівень: $2500 £$ фунтів стерлінгів; та 5 рівень: 5000 £ фунтів стерлінгів.

Під час постанови вироку суд може вказати деякі процесуальні особливості виконання штрафу. Відповідно до ст. 162 Закону про кримінальну юстицію 2003 року суд видає «наказ про встановлення фінансових обставин», де приписує особі надати відомості про своє фінансове становище. Також може бути визначений кінцевий строк виплати, розстрочка виплати штрафу частинами й у конкретні дати. У разі невиконання або несвоєчасного виконання вимог, покладених за вироком суду на засудженого, суд замінює штраф на тюремне ув'язнення зі встановленням певного строку або на «суспільне засудження» тощо. Так, за рішенням суду Корони, при несплаті частки штрафу в сумі не більше 200 £ фунтів стерлінгів, максимальний термін ув'язнення може становити до 7 днів, не більше 500 £ фунтів стерлінгів 14 днів, не більше $1.000 £$ фунтів стерлінгів - до 28 днів, не більше $2.500 £$ фунтів стерлінгів - до 
45 днів, не більше 5.000 £ фунтів стерлінгів - до 3 місяці, не більше 10.000 £ фунтів стерлінгів - до 6 місяців, не більше 20.000 £ фунтів стерлінгів до 12 місяців, не більше 50.000 £ фунтів стерлінгів - до 18 місяців, не більше 100.000 £ фунтів стерлінгів - до 2 років, не більше $250.000 £$ фунтів стерлінгів - до 3 років, не більше 1 млн. є фунтів стерлінгів - до 5 років, та більше 1 млн. £ фунтів стерлінгів - до 10 років (ст. 139 (2), (4) Закону про повноваження кримінальних судів 2000 року).

Якщо штраф було замінено «суспільним засудженням» (ст. 199 Закону про кримінальну юстицію 2003 року), «комендантською годиною» (ст. 204 Закону), вимогою відвідування спеціального центру присутності для осіб віком до 25 років (ст. 214 Закону) або позбавлення чи отримання права керувати транспортними засобами (ст. 301 Закону), то його дія припиняється після повної виплати штрафу. Водночас термін позбавлення чи отримання права керувати транспортними засобами не може бути більш ніж 12 місяців. У разі часткової виплати штрафу термін «суспільного засудження», «комендантська година», вимоги відвідування спеціального центру присутності для осіб віком до 25 років або позбавлення чи отримання права керувати транспортними засобами скорочується пропорційно виплаченій сумі (ч. 7 ст. 300 та ч. 3 ст. 301 Закону).

Висновки. Проведений аналіз наукових досліджень та законодавчих приписів про особливості кримінальних покарань щодо фізичних осіб в Англії повинен сприяти європейський адаптації українського законодавства із цього питання. Поступове подолання труднощів щодо розуміння різних аспектів інших кримінально-правових систем та отримання позитивного закордонного досвід набуває свої корисності, має перспективи подальшого розвитку.

\section{Література}

1. Уголовное право зарубежных государств. общая часть: ученик для бакалавриата и маги- стратуры /под ред. А.В. Наумова, А.Г. Кибальника. Москва : Изд-во Юрайт, 2018. 285с.

2. Додонов В.Н. Сравнительное уголовное право. Монография. Общая часть / Додонов В.Н. ; под общ. и науч. ред.: Щерба С.П. Москва : Юрлитинформ, 2009. 448 с.

3. Есаков Г.А., Крылова Н.Е., Серебренникова А.В. Уголовное право зарубежных стран. Москва : Проспект, 2009. 336с.

4. Яценко С.С. Основні питання загальної частини кримінального права іноземних держав : навч. посібник; Київ. нац. ун-т ім. Тараса Шевченка. Київ : ВД «Дакор», 2013. 168 с.

5. Старовойтова Ю.Г. Загальна частина кримінального права Англії та США: (навчальний посібник) / Ю.Г. Старовойтова. Київ : Атіка, 2012. 104 с.

6. Уголовное право зарубежных стран. В 3 т. Том 1. Общая часть. Англия, США: учебник для бакалавриата и магистратуры / отв. ред. Н.Е. Крылова. 5-е изд., перераб. и доп. Москва : Изд-во Юрайт, 2019. 240 с.

7. Альтернативы смертной казни (информационный пакет). Международная тюремная реформа. Апрель, 2011. 29 с. URL: //www.penalreform.org. (дата звернення: 29.07.2020).

8. House of Commons Justice Committee. The role of the Probation Service Eighth Report of Session. 2010. 12. $133 \mathrm{p}$.

9. Шапоренко О.И. Институт пробации как альтернатива лишения свободы. Науков. вісник м/н. гуман. ун-ту: 3б.наук.праць. Серія юриспруденція. Одеса, «Фенікс». 2011. Вип. № 2. 214 с.

10. Стивенс Питс Пробация в Англии и Уэльсе. 2016. URL: www.slideshare.net. (дата звернення: 26.07.2020).

11. Бурдо Е.П. Наказание по общему праву Англии, Уэльса и США (сравнительно-правовое исследование). Автореф. дис. ... к.ю.н. 12.00.08. Казань, 2007. 24 с.

Самошенко I. В., кандидат юридичних наук, доцент, доцент кафедри кримінального права № 2 Національного юридичного університету імені ярослава Мудрого 